\title{
Kekuatan Hukum Atas Gugatan Perdata Yang Diajukan Secara Lisan di Pengadilan Negeri Padangsidimpuan
}

\author{
Ridwan Rangkuti \\ Universitas Muhammadiyah Tapanuli Selatan \\ Email : ridwan.rangkuti@um-tapsel.ac.id
}

\begin{abstract}
Abstrak
Dalam kehidupan bermasyarakat, banyak menghadapi masalah-masalah yang serba komplek, terjadi pelanggaran yang sifatnya personal atau pribadi, bilamana terjadi pelanggaran hak sudah tentu adanya penyelesaian yang baik serta menurut aturan hukum yang berlaku dalam masyarakat berupa perundangundangan. Untuk penyelesaiannya ada dua jalan yang dapat ditempuh yaitu dengan jalan berdamai tanpa melibatkan pihak pemerintah atau mengajukannya kepada yang berwenang dalam hal ini adalah lembaga peradilan dalam hal ini yaitu Pengadilan Negeri.

Dalam mengajukan permasalahan tersebut tentu sudah harus membuat surat gugatan atau tuntutan hak dalam ini disebut dengan gugatan dimana gugatan ini ditulis atau dikomputer yang bermaterai atau kertas segel.

Dari ulasan yang telah dikemukakan di atas, dalam kaitan dengan pokok masalah dalam penulisan ini maka perumusan masalah dalam penelitian ini adalah :

1. Bagaimanakah kekuatan hukum atas gugatan perdata yang diajukan secara lisan ?

2. Apakah hambatan-hambatan yang timbul dalam pembuktian perkara perdata atas gugatan yang diajukan secara lisan. ?

Metode yang dipergunakan dalam menganalisa permasalahan penulis akan menggunakan metode penelitian secara deskriptif dengan cara Library Research dan Field Research dengan memakai teknik pengumpulan data dengan melalui interview dan studi dokumentasi, dan setelah data terkumpul akan diuji melalui teknik pengujian deduktif dan induktif.

Dari data yang dihasilkan dalam penelitian bahwa gugatan yang diajukan secara lisan adalah syah secara hukum dan tidak ada masalah soal kekuatan hukum, hanya saja yang merupakan hambatan pihak penggugatnya tidak secara jelas mamajukan dasar-dasar pembuktiannya jika dikaitkan dengan dalil-dalil yang digugat.

Keberadaan gugatan jika pengajuannya di lakukan lisan khususnya di pengadilan negeri Padangsidimpuan kenyataan gugatan lisan tersebut masih ada diterapkan.
\end{abstract}

Kata kunci: Gugatan Perdata, Kekuatan Hukum

\section{PENDAHULUAN}

Permasalahan yang timbul dalam masyarakat bukanlah suatu hal yang baru lagi, sehingga dalam berbagai aspek kehidupan memerlukan peraturanperaturan hukum agar tidak terjadinya benturan hukum antara sesame masyarakat dalam memenuhi kebutuhannya

Sehingga ketika timbul permasalahan tersebut penyelesaiannya ada dua jalan yang dapat ditempuh yaitu dengan jalan berdamai tanpa melibatkan pihak pemerintah atau mengajukan gugatan kepada yang berwenang yaitu Pengadilan Negeri.

Adapun gugatan ini adalah merupakan salah satu kelengkapan administrasi pengadilan negeri dalam menyelesaikan suatu masalah perkara perdata.

Oleh karena itu kelengkapan administrasi hanya dapat terpenuhi apabila ditempuh dengan pengajuan suatu gugatan perdata baik secara lisan maupun tulisan. Dalam pengajuan gugatan ini, penggugat menyampaikannya dihadapan Ketua Pengadilan dan dicatat oleh Panitera apa saja yang diterangkan atau dikemukakan didalam gugatan mengenai tentang duduk persoalannya serta identitas para pihak yang berperkara. '

Berdasarkan hal tersebut di atas penulis tertarik untuk mengangkat topik ini menjadi judul penelitian skripsi yakni : "Kekuatan Hukum Atas Gugatan Perdata Yang Diajukan Secara Lisan di Wilayah 
Hukum Pengadilan Negeri

Padangsidimpuan".

\section{Perumusan Masalah}

Menurut Sumadi Suryabrata bahwa permasalahan adalah : Kalau ada kesenjangan (gap) das sollen dan das sain ada perbedaan antara apa yang seharusnya dan apa yang ada dalam kenyataan antara apa yang diperlukan dan apa yang tersedia antara harapan dan kenyataan dan sejenis" (1983:66).

Dari latar belakang masalah dan pengertian masalah yang dikemukakan di atas maka dapat ditarik perumusan Masalah sebagai berikut :

1. Bagaimanakah kekuatan hukum atas gugatan perdata yang diajukan secara lisan?

2. Hambatan-hambatan apa yang timbul dalam pembuktian perkara perdata yang gugatannya diajukan secara lisan?

\section{Tujuan Penelitian}

Adapun tujuan yang ingin dicapai pada penulisan penelitian ini adalah sebagai berikut :

1. Untuk mengetahui bagiamanakah kekuatan hukum atas gugatan perdata yang dijukan secara lisan

2. Untuk mengetahui hambatan-hambatan apa yang timbul dalam pembuktian perkara perdata yang gugatannya diajukan secara lisan.

\section{METODE PENELITIAN}

Di dalam melakukan penelitian diperlukan metode penelitian, yang sangat besar peranannya di dalam menentukan kesimpulan, sebagai bagian akhir dari penulisan penelitian, maka untuk kepentingan tersebut dengan memperhatikan permasalahan yang diteliti. Secara garis besarnya penelitian yang penulis buat adalah sebagai berikut:

\section{Lokasi Penelitian}

Lokasi penelitian ini adalah Pengadilan Negeri Padangsidimpuan. Sebagai pusat dan juga lokasi-lokasi yang lain sesuai dengan objek penelitian

\section{Pendekatan Penelitian}

Dalam penelitian ini penulis menggunakan pendekatan secara personal terhadap sumber informan yang dibutuhkan baik data primer maupun pada tataran sumber data sekunder.

\section{Jenis Penelitian}

Jenis penelitian yang dibuat adalah penelitian Observational Research dengan cara survey yakni, penelitian yang dilaksanakan di lapangan untuk memperoleh data yang diperlukan dan akhirnya dapat menjawab permasalahan yang dihadapi. dilakukan dengan menganalisa berbagai bahan bacaan, penulis juga melakukan kegiatan riset lapangan guna memperoleh data melalui perkembangan dalam praktek.

\section{Populasi}

Populasi dalam pembahasan ini semua orang-orang yang memiliki kesamaan perkara dalam bidang gugatan perdata pada ruang lingkup Pengadilan Negeri Padangsidimpuan, sehingga penulis perlu menetapkan pengambilan sampel yang akan dijadikan contoh dalam penelitian.

\section{Sampel}

Mengingat jumlah Populasi yang demikian kompleks maka penulis mengambil sampel dari penelitian ini adalah sesuai dengan penelitian ini yakni Hakim Ketua Pengadilan Negeri serta orang orang yang terlibat secara langsung dengan perkara ini.

\section{Sumber Data}

Sumber dari yang dipergunakan dalam penelitian ini yakni :

1. Data Primer yaitu : data yang diperoleh langsung dari responden, yaitu data yang diperoleh dari Ketua Pengadilan Negeri dan lain-lain yang berkepentingan langsung

2. Data Sekunder yaitu : data yang tersedia dalam bentuk tertulis yang diperoleh dari pustaka secara literature, peraturan perundang-undangan dan pendapat para ahli yang relevan. 


\section{Alat Pengumpul Data}

Alat pengumpul data yang penulis gunakan dalam penelitian ini :

1. Interview (wawancara), yakni : wawancara langsung dengan instansi yang menurut anggapan penulis dapat memberikan data yang diperlukan.

2. Kuesioner yaitu alat pengumpul data dengan cara mengajukan daftar pertanyaan secara tertulis pihak-pihak yang bersangkutan.

\section{Analisa dan Interpretasi Data}

Setelah data terkumpul, baik data primer maupun data sekunder yang diperoleh penulis dari lapangan dengan interview selanjutnya diolah dengan mengelompokkan data menurut jenisnya. Data yang bersumber dari kuesioner akan disajikan dalam bentuk tabel. Kemudian dilakukan pembahasan berupa penafsiran yang dihubungkan dengan teori-teori hukum, dokumen-dokumen dan data lain serta membandingkannya dengan pendapat para ahli.

Sedangkan metode yang penulis gunakan dalam pengambilan kesimpulan yakni :

- Deduksi , yaitu mengambil kesimpulan dari hal-hal yang bersifat khusus atau konkritnya berdasarkan perangkat hukum positif, sebagai landasan umum dicoba ditarik kesimpulan terhadap kasus yang dihadapi mengenai yurisprudensi.

- Induksi, yaitu mengambil kesimpulan dari hal-hal yang bersifat umum dari selama proses penelitian berlangsung untuk ditarik suatu kesimpulan kepada hal-hal yang bersifat khusus.

\section{HASIL DAN PEMBAHASAN}

\section{Ketentuan Umum Beracara dalam Peradilan Perdata}

Dalam pembagian hukum dibidang perdata, hukum acara perdata disebut pula dengan hukum perdata formil Formeel Recht, yaitu hukum yang mengatur bagaimana caranya menjamin ditegakkannya hukum perdata materiil Matereel Recht, Substantive law.
Dengan kata lain menurut pendapat atau penafsiran para ahli bahwa hukum acara perdata adalah: " Rangkaian peraturan-peraturan yang membuat cara bagaimana orang harus bertindak dan dimuka pengadilan dan cara bagaimana pengadilan itu harus bertindak" (Wirjono Prodjodikoro, 1984:13)

Sebagai perbandingan tentang pengertian hukum acara perdata tersebut lebih lanjut Kansil menjelaskan bahwa "Hukum acara perdata adalah rangkaian peraturan hukum yang menentukan bagiamana cara-cara mengajukan ke depan pengadilan perkara-perkara keperdataan dalam arti luas (meliputi juga hukum dagang) dan cara-cara melaksanakan putusan-putusan (vonnis) hakim juga diambil berdasarkan peraturanperaturan tersebut" (1980:316).

Dan oleh karena itu, jika ditinjau dari proses peradilan perdata ini, kiranya hukum acara perdata dapat digolongkan kedalam tiga tahap: Tahap pendahuluan, tahap penentuan dan tanap pelaksanaan. Tahap Pendahuluan merupakan persiapan menuju kepada diadakan pemeriksaan peristiwa dan pembuktian sekaligus sampai kepada putusannya. Sedangkan dalam tahap pelaksanaan diadakan pelaksanaan dari putusan (Sudikno Mertokusumo, 1982:5).

Untuk jelasnya aturan-aturan hukum acara perdata tersebut sebagaimana ditegaskan dalam undang-undang darurat Nomor 1 tahun 1951 pada pasal 5 sebagaimana yang ditegaskan oleh Sudikno Mertokusumo, berikut ini : Bahwa yang dimaksud oleh undang-undang Darurat Nomor 1 Tahun 1951 tersebut tidak adalah Het Herziene Indonesiach Reglement (HIR atau Reglemen Indonesia yang diperbaharui : S. 1884 No. 16, S. 1941 Nomor 44) unutk daerah Jawa dan Madura, dan Recht Sreglement Buitengewesten (RBG. Atua Reglemen daerah seberang : S. 1927 No. 227) untuk daerah luar Jawa dan Madura

Beberapa azas hukum perdata yang penting didalam suatu sidang yang akan memeriksa gugatan yang diajukan para pihak yang bersengketa atau berperkara adalah :

a. Hakim bersifat menunggu 
Azas yang terpenting dalam hukum acara perdata adalah sikap hakim yang passif, artinya didalam ketentuan hukum acara perdata ini tidak ada kewenangan bagi hakim untuk aktif didalam memeriksa perkara. Penegasan tersebut di atas bahwa pengajuan tuntutan hak lewat hukum acara perdata ada pada pihak, hal ini sebagaimana diatur dalam ketentuan pasal 118 HIR, 142 Rbg, yang menegaskan hakim bersikap menunggu datangnya tuntutan hak yang diajukan kepadanya, atau yang lebih dikenal dengan istilah ludex ne Procedur ex office.

b. Mendengar Kedua Pihak

Didalam hukum acara perdata kedua belah pihak yang bersengketa harus mendapat perlakuan yang sama, tidak memihak dan harus masing-masing mendapat suatu kesempatan untuk membuktikan dirinya.

c. Beracara dikenakan Biaya

Beracara dalam sidang peradilan perkara pada azasnya dikenakan biaya, dimana pengenaan masalah biaya ini meliputi biaya kepeniteraan dan biaya untuk pemanggilan, pemberitahuan para pihak serta biaya materai.

d. Tidak ada keharusan mewakili

Dalam ketentuan beracara hukum perdata kiranya undang-undang tidak ada memberi keharusan para pihak untuk mewakili kepada orang lain,

\section{Pengertian Surat Gugatan Perkara Perdata}

Adapun untuk memberi pengertian tentang yang dimaksud dengan surat gugatan sebenarnya sangatlah sulit, dimana hal ini disebabkan tidak adanya suatu batasan yang pasti dalam bukunya John Loudeo, telah memberi pengertian sebagai berikut : Dalam arti luas dan abstrak maka suatu surat gugtan mempunyai tujuan menjamin terlaksananya tertib hukum dalam bidang hukum perdata, sedangkan dalam arti sempit ia adalah suatu tata cara untuk memperoleh perlindungan hukum dengan bantuan penguasa, suaut tata cara yang mengandung suatu tuntutan oleh seorang tertentu melalui saluran-saluran yang syah.
Berdasarkan pengertian batasan sebagaimana diuraikan di atas kiranya surat gugatan dapat diartikan sebagai suatu upaya/tata cara dalam menuntut hak, artinya dengan gugatan ini seseorang minta perlindungan hukum atas penentuan suatu hak, karenanya dengan batasan pengertian gugatan di atas jelas surat gugatan ini adalah suatu upaya didalam mana seseorang yang ingin memperjuangkan haknya kembali sebagai akibat dari tindakan dari orang lain yang telah menguasainyta secara tidak syah.

Atau dengan kata lain bahwa surat gugatan ini dapat juga diartikan sebagai suatu cara untuk minta penyelesaian suatu sengketa, yang mana dalam surat gugatan ini aa seorang atau lebih yang merasa bahwa haknya atau mereka telah dilanggar, sedang dilain pihak orang yang merasa dilanggar haknya tidak mau secara suka rela melakukan sesuatu yang diminta untuk menentukan siapa yang benar dan berhak.

Dalam ketentuan hukum acara perdata bahwa untuk memberi isitlah tentang apa yang dimaksud dengan surat gugatan disebut sebagai Rechtsvordering atau dagvarrding yaitu sebagai permulaan atau perkara perdata di muka pengadilan.

Dagvaarding atau surat gugat adalah berupa suatu permohonan gugat yang diajukan oleh pengggugat kepada hakim, yang maksudnya supaya hakim memanggil kedua belah pihak akan menghadap persidangan hakim dalam mana akan dilakukan pemeriksaan perkara perdata antara kedua belah pihak sebagai diuraikan dalam permohonan gugat itu (Wirjono Prodjodikoro, 1984:34).

\section{Syarat - Syarat Isi Gugatan}

Berdasarkan hukum acara perdata, kiranya ada dua pandangan yang menegaskan bagaimana syarat isi gugatan tersebut harus dirumuskan, yaitu:

a. Substansi Ringstheori

Berdasarkan pendapat atau pandangan teori ini maka pada surat gugatan tidak cukup peristiwa hukum yang menjadi dasar tuntutan, akan tetapi harus pula disebutkan kejadian-kejadian yang nyata yang mendahului peristiwa hukum yang menjadi dasar gugatan itu atau yang menjadi sebab timbulnya peristiwa hukum itu. 
b. Individualis Ringstheorie

Teori individualisasi menyatakan bahwa kejadian-kejadian yang disebutkan dalam gugatan harus cukup menunjukkan adanya hubungan hukum yang menjadi dasar tuntutan, tanpa disebutkan dasar terjadinya ata sejarah terjadinya, karena hal itu dapat dikemukakan dalam persidangan pengadilan dengan disertai pembuktian. (Hapsoro, 1974:9)

c. Identitas Para Pihak

Yang dimaksud dengan indentitas para pihak tidak lain dari ciri-ciri daripada penggugat dan tergugat, seperti nama serta tempat tinggalnya, umur serta status kawin atua tidak lain sebagainya yang dapat menunjukkan status para pihak sebagai warga negara. Pasal 118 ayat 1 HIR bahwa pengadilan Negeri ditempat tinggal tergugatlah yang berkuasa memeriksa gugatan yang dimajukan. Pasal 118 ayat 2 $\mathrm{HIR}$, pengadilan negeri setempat tinggal salah seorng dari tergugat yang dipilih oleh penggugat, jika terdapat lebih dari seorang penggugat (Wantjik Saleh, 1979:16).

d. Pundammentum Petendi

Sebagai syarat ini gugatan yang kedua ini juga sering disebut istilah Middelen yaitu dalil-dalil konkrit tentang adanya hubungan hukum, yaitu dasar serta alasan-alasan tuntutan. Lebih lanjut sebagaimana dinyatakan oleh John Z. Loudoe dalam bukunya bahwa "Fundamentum petendi berarti upaya-upaya dan pokok tuntutan. Upaya-upaya tersebut terdiri dari alsan fakta dan dasar hukum, sedangkan yang dimaksud dengan pokok tuntutan tidak lain daripada suatu konklusi yang jelas dan tertentu mengenai apa yang dituntut" (1983:120).

\section{e. Petitum ( tuntutan)}

Dalam teori hukum secara perdata istilah petitum dapat juga disebut sebagai " Oderwerp ban deieis yaitu apa yang dituntut oleh penggugat atau kesimpulankesimpulan dari gugatan.

Tuntutan yang tidak jelas atau tidak sempurna akan dapat berakibat tidak diterimanya tuntutan tersebut. demikian pula gugatan yang berisi pernyataanpernyataan yang bertentangan satu sama lain yang disebut obscuur libel berakibat tidak diterimanya gugatan tersebut.
Jika dilihat dari kegunaannya mencantumkan petitum yang sifatnya subsidair tersebut dalam proses beracara pada perkara-perkara perdata adalah : Agar kalau tuntutan atau petitum primair ditolak/tidak diterima hakim masih ada kemungkinan dikabulkannya gugatan yang didasarkan atas kebebasan dari hakim serta keadilan. Jadi tuntutan atau petitum subsidair ini hanya merupakan tuntutan cadangan.(Sudikno Mertokusumo, 1982:41)

\section{Tata Cara Pengajuan Gugatan Pengadilan Perkara Perdata}

Dalam suatu sengketa perdata yang terjadi, pihak pertama mengajukan gugatan dengan surat permintaan yang ditanda tangani, Setelah ditanda tanganinya suatu gugatan dan telah memenuhi peraturan biaya materai yang kemudian disertai dengan beberapa salinannya, maka selanjutnya gugatan harus didaftarkan ke paniteraan Pengadilan Negeri. Yang kemudian saat memasukkan gugatan tersebut pihak berpekara diharuskan untuk membayar/menyetor biaya perkara kepada kepaniteraan, biaya pemanggilan dan pemberitahuan kepada pihak lawan. dibuat dalam beberapa rangkap sebagai penentuan administrasi persidangan, yang mana satu helai sebagai asli dari gugatan tersebut adalah untuk pengadilan dan satu helai lagi untuk penggugat, yang kemudian ditambah dengan salinan untuk kepentingan pihak tergugat. Yang kemudian cara pengajuan gugatan tersebut secara tegas diatur dalam ketentuan pasal 118 HIR yang menegaskan bahwa gugatan yang dimajukan oleh penggugat kepada ketua pengadilan negeri dapat dilakukan secara tertulis maupun secara lisan sebagaimana yang diatur dalam pasal 120 HIR.

Sedangkan bagi pihak penggugat yang tidak dapat menulis gugatan dapat diajukan secara lisan pada ketua pengadilan negeri yang bersangkutan, bagi pengajuan gugatan secara lisan pihak penggugat harus datang sendiri menghadap panitera pengadilan negeri untuk mencatat segala sesuatu yang dikemukakan penggugat. 
Setelah menguraikan tata cara pengajuan gugatan dalam penulisan ini, dimana ketentuan lain yang penting untuk dibahas dalam proses pengajuan gugatan ini adalah yang berkaitan dengan ketentuan penambahan dan perubahan suatu gugatan yang telah dimasukkan sebelumnya, misalnya oleh karena semua ahli waris diikut sertakan dalam suatu gugatan maka untuk lebih menjamin kekuatan gugatan dapat ditambah dengan menarik ahli waris lainnya dalam gugatan tersebut. jadi dengan demikian jelaslah ukuran penambahan gugatan yang diperbolehkan, bahwa penambahan tersebut hendaknya tidak merugikan pihak lain sepertinya penambhan petitum yang sebelumnya tidak ada dimohonkan.

Segala ketentuan-ketentuan yang berhubungan dengan masalah gugatan sebagai dasar penuntutan hak oleh seseorang benar-benar memerlukan proses peradilan yang memenuhi aturan hukum. Sebab bagaimanapun dengan posisi perkara perdata sifatnya menyangkut hakhak sipil masyarakat, menyebabkan hakim sebagai aparat hukum harus mampu mengeluarkan suatu putusan yang seadiladilnya, bagi individu-individu yang bersengketa.

\section{PEMBAHASAN}

Mengingat sifat passif yang dimilikinya seorang hakim dalam memberiksa dan menyidangkan perkara-perkara perdata, menyebabkan ruang lingkup atau luasnya suatu sengketa yang diajukan para pihak pada azasnya ditentukan oleh para pihak itu sendiri. Sedangkan di pihak lain hakim peradilan perdata hanya sekedar membantu para pencari keadilan dalam mencari jalan keluar atau jalan tengah sehubungan dengan adanya ketidak serasian, hubungan hukum antara pihak.

Bagi pihak yang merasa tidak adanya keserasian hubungan hukum yang terjadi maka salah satu jalan untuk mencari serta memutuskan siapa yang berhak, adalah dengan cara mengajukan gugatan kepada pengadilan negeri dengan suatu permohonan agar dapat ditetapkan. Oleh karena itulah dilihat dari kepentingan tersebut surat gugatan yang diajukan pihak yang merasa dirugikan ini benar-benar merupakan kunci bagi terbukanya sidang pengadilan dalam perkara perdata, dan sejalan dengan itu pula masalah pentingnya surat gugatan ini tidak lain sebagai suatu acuan bagi hakim bahwa ia memeriksa tidak boleh terlepas dari gugatan itu.

Penegasan tersebut di atas hal ini sejalan dengan apa yang diutarakan oleh hakim bahwa sejalan dengan aturan perundang-undangan yang berlaku hakim mempunyai batasan -batasan tertentu terhadap suatu gugatan, dimana suat perkara yang digugat hakim dilarang menjatuhkan suaut putusan dari apa yang dimohonkan dalam gugatan.

Artinya dalam mengadili sengketa perkara perdata ini hanya terdapat peristiwa yang disengketakan sejalah yang harus dibuktikan, dan atas peristiwa tersebut hakim mewajibkan pada pihak untuk saling membuktikan kebenaran masing-masing.

Namun demikian menurut penjelasan beliau lebih lanjut dimana pengertian passif dari sikap hakim dalam memeriksa perkara perdata ini tidaklah mutlak adanya, yang mana pengertian passif tersebut adalah dalam menentukan luasnya pokok sengketa tidak boleh menambah dan mengurangi apa yang dirumuskan penggugat dalam gugatannya.

Sedangkan kedudukan hakim sebagai pimpinan sidang, hakim tetap aktif dan harus berusaha sekeras-kerasnya mengatasi segala hambatan dan rintangan untuk mencapai keadilan, juga menanyakan dan menggali kebenaran tuntutan para pihak sebagaimana yang dibuatnya dalam surat gugatan. Sehubungan dengan penjelasan hakim tersebut di atas kiranya tepatlah apa yang ditentukan dalam hukum acara perdata tersebut bahwa kedua belah pihak yang bersengketa diharuskan untuk hadir, sebab dengan adanya gugatan ini jelas menunjukkan pentingnya perlakuan yang sama bagi para pihak untuk saling menanggapi.

Untuk ini lebih lanjut hakim menegaskan bahwa untuk menanggapi gugatan yang diajukan hakim tidak boleh 
menerima keterangan dari salah satu pihak saja dan juga tidak diperbolehkan hanya membenarkan keterangan satu pihak saja akan tetapi masing-masing pihak harus mampu membuktikan gugatan disatu pihak dan dilain pihak harus mampu membantah apa yang digugat tersebut.

Berdasarkan uraian-uraian tersebut di atas kirany jelas nampak bagaimana pentingnya surat gugatan dalam mengadili perkara-perkara perdata dimana alasan alasan serta argumentasi yang harus dibuktikan sidang pemeriksaan perkara itu tertuang dalam gugatan tersebut.

Maka oleh sebab itulah gugatan ini dapat dikatakan sebagai pedoman, dilanjutkan atau setidaknya suatu tuntutan hak disidang pengadilan. disamping hal tersebut masalah pentingnya gugatan dalam peradilan perkara perdata karena ia merupakan suatu cara atau wadah bagi pemenuhan suatu hak, maksdunya bagi setiap yang akan menuntut haknya kembali harus benar-benar dapat menegaskan dalam gugatan. Namun tidak berarti setiap tuntutan hak seseorang dalam suatu gugatan dikabulkan, melainkan tuntutan hak tersebut harus mempunyai kepentingan hukumnya dan dibuktikan melalui data dan alat-alat bukti yang ada.

Kaitannya dengan penjelasan tersebut di atas hakim menyatakan bahwa tuntutan hak tersebut masih harus dibuktikan dengan latar belakang hubungan yang terjadi. Jadi kalau sebelumnya memang tidak mempunyai hubungan hukum kemudian langsung menggugat seseorang jelas hal ini tidak punya dasar. Yang mana hal ini sesuai dengan salah satu putusan mahkamah Agung RI tanggal 7 Juli tahun 1971 Nomor : 294 K/Sip/1971 yang menyatakan bahwa gugatan harus diajukan oleh orang yang mempunyai suatu hubungan hukum.

Dengan demikian jika ditarik suatu kesimpulan baha tuntutan hak yang dimaksudkan di atas tidak lain sebagai tuntutan perdata, yaitu tuntutan hak yang mengandung sengketa perdata dan lazimnya hal ini dituangkan kedalam suatu gugatan. Maka dengan demikian jika ditinjau dari pentingnya surat gugatan ini, jelas perkara perdata yang dimuat dalam suatu gugatan harus didasarkan atas adanya sengketa hubungan hukum.

Sebagai perbandingan dalam menanggapi surat gugatan ini, bahwa pentingnya guatna ini dalam perkara perdata tidak lain sebagai dasar pengambilan suatu hak maksudnya adanya gugatan yang dimajukan seseorang penggugat baik atas upaya sendiri atuapun melalui kuasa hukum kiranya dalam gugatan inilah dijabarkan seluruh keluhan penggugat yagn merasa hak-haknya telah dirugikan.

Berdasarkan seluruh uraian tentang anggapan tesebut di ats maka dapat disimpulkan bahwasanya keberadaan gugatna dalam proses peradilan perdata tidak terlepas dari kepentingan penegakan hukum juga keadilan. Dikatakan demikian karena tanpa suatu gugatan yang baik kiranya seseorang yang akan menuntut hak melalui peradilan, tidak mungkin akan dapat terwujudnya dan tidak mungkin dilakukan pemeriksaan atas sengketa hubungan hukum yang terjadi diantara kedua belah pihak.

Sedang disisi lain dapat pula disimpulkan bahwa dengan gugatan yang diajukan kehadapan siang pengadilan, kiranya dalam gugatan inilah dapat diketahui bagaimana keinginan para penguggat agar diputuskan, ditetapakan maupun diperintahkan oleh hakim. Sehingga dapat dinyatakan gugatna dalam suatu perkara perdata, tidak lain sebagai suatu permohonan penyelesaian terjadinya sengketa hukum.

\section{Praktek Pengajuan Gugatan Lisan dalam Perkara Perdata}

Dengan mengingat pentingnya surat gugatan dalam peradilan pekara perdata maupun terhadap kepentingan pemenuhan suatu hak, kiranya pihak yang berkepentingan secara langsungslah semestinya mengajukan persoalan tersebut kepada pengadilan negeri setempat. Karena bagaimanapun kemampuan penggugat untuk mengutarakan peristiwa yang dia alami, hal ini harus juga mendapat pengarahan dari pihak pengadilan tentang hal-hal yang penting dimuat pada surat gugatan. 


\begin{abstract}
Maka sehubungan dengan penegasan tersebut di atas hakim pengadilan negeri Padangsidimpuan menyatakan bahwa gugatan yang mau diajukan secara lisan hendaknya harus langsung pihak-pihak yang berperkara, artinya tidak perlu dikuasakan kepada pihak lain sebab akan lebih akan persoalannya jika para pihak sendiri itu yang menjelaskan.
\end{abstract}

Penjelasan hakim tersebut di atas kiranya didasarkan keapda salah satu yurisprudensi Putusan Pengadilan Tinggi Ujung Pandang tanggal 11 April 1972 Nomor $16 / 1970 / P T$, yang menegaskan bahwa wewenang pengajuan dengan lisan tidak berlaku bagi kuasa. Yang mana hal ini didasarkan bahwa akan lebih terjaminlah jika pihak itu sendiri yang mengutarakannya. Namun demikian untuk menanggapi ketegasan menguasakan gugatan lisan kepada suatu kuasa hukum, lebih lanjut dinyatakan bahwa dari pada mengajukan gugatan secara lisan langsung kepada pengadilan negeri akan lebih baik kepada kuasa hukum dimana hal ini untuk menjaga keobyektifan persidangan.

Mengenai pernyataan hakim tersebut, di atas kiranya sangat mendekati kebenaran, dikatakan demikian karena dengan pengajuan langsung keapda pengadilan negeri atau gugatan secara lisan, tentunya sedikit banyak akan merugikan tergugat sebab bagaimanapun dengan adanya campur tangan pengadilan sedikit akan mempengaruhi kebenaran suatu gugatan.

Maka oleh sebab itu jika melalui seorang kuasa hukum tentunya akan muncul suatu kenetralan dalam pemeriksaan sidang nantinya, apa lagi tergugat juga didampingi oleh kuasa hukum.

Adapun cara sering diterapkan para pengadilan Negeri Padangsidimpuan tentang pengajuan gugatan secara lisan ini, lebih lanjut seperti ditegaskan oleh hakim bahwa dalam proses peradilan perkara perdata dimulai dengan mengajukan gugatan, dan bilamana yang akan mengajukan itu tersebut adalah seorang penggugat yang tidak bisa menulis atau membaca maka gugatan lisan tersebut bisa diajukan kepada ketua Pengadilan Negeri.

Yang kemudian seterusnya oleh ketua pengadilan negeri akan diperintahkan kepada panitera ditulis kembali, dan inilah yang akan dibacakan dalam pemeriksaan sidang pengadilan.

Maka sehubungan dengan penjelasan cara pengajuan gugatan secara lisan pada pengadilan negeri, khususnya pada wilayah hukum pengadilan negeri padangsidimpuan kiranya salah satu yang menjadi tanggungjawab penggugat dalam gugatannya tersebut halnya masalah administrasi saja, seperti misalnya pembayaran uang perkara dan penanda tanganan gugatan yagn sudah dituliskannya.

Sedangkan dilain pihak segi yang berkaitan dengan kebenaran apa yang ditulis dalam gugatan tersebut sepenuhnya tergantung kepada pihak pengadilan, maka oleh sebab itulah sebelum dijadikan sebagai dasar pemeriksaan sidang hendaknya harus terlebih dahulu dibacakan dihadapan penggugat tersebut, yang aman dengan dibacakannya gugatan tersebut ia akan mengetahui dan bisa mengikuti jalannya pemeriksaan selanjutnya.

Kemudian yang penting juga sehubungan gugatan perdata yang diajukan secara lisan ini, adalah sehubungan dengan berkuasanya hakim untuk memberi nasehat kepada seseorang penggugat. Dimana dengan bantuan panitera mencatat gugatan yang diutarakan penggugat secara lisan tersebut, hendaknya secara rinci harus diterangkan kembali kepada pihak yang berkepentingan. Yang mana hal ini tidak lain hanyalah untuk menghindarkan dari kurang jelas dan kurang lengkap gugatan tersebut yang seterusnya akan dapat terwujud suatu gugatan yang pasti dan tidak merugikan siapapun pihak yang berkepentingan.

Maka sehubunan dengan penjelasan tersebut di atas, lebih lanjut hakim pengadilan negeri Padangsidimpuan menyatakan bahwa gugatna lisan yang diajukan berdasarkan hak yang diberikan oleh ketentuan pasal 120 HIR JO pasal 144 ayat (1) Rgb tersebut hendaknya harus 
benar-benar mendapat perhatian yang khusus jika dibandingkan dengan gugatan yang diajukan secara tertulis yang mana hal ini mengingat banyaknya sarat isi gugatan tersebut yang harus dipenuhi, jadi bilamana tidak benar-benar mendapat perhatian khusus hal ini akan dapat menimbulkan kerugian pihak yang disebabkan tidak terbuktinya gugatan tersebut setelah pembuktian.

Sehubungan dengan penggugat yang tidak bisa menulis untuk menyusun suatu gugatan, sepenuhnya ditangan para kuasa hukum jika memang gugatan tersebut tidak mampu dilakukan para pihak dengan secara tertulis.

Berdasarkan seluruh argumentasi tersebut di atas, ternyata telah dapat diketahui bagaimana tata cara pengajuan gugatan secara lisan kepada pengadilan negeri, yang mana jika digunakan tersebut memang diajukan para pihak secara lisan hal ini haruslah melalui panitera perkara yang akan menyidangkan suatu perkara yang gugatannya itu diajukan secara lisan, untuk kemudian dikonslutasikan kepada hakim.

Sehingga dari penegasan tersebut kiranya jelaslah bahwa gugatan secara lisan yang diajukan oleh para pihak penggugat, tetap terbuka kemungkinan bagi penuntutan suaut hak dihadapan sidang pengadilan.

Dimana kesempatan gugatan secara lisan ini masih tetap dimungkinkan tidak lain mengingat masih banyaknya pihak yang tidak tahu tulis baca, sehingga untuk menyamaratakan kesempatan mencari perlindungan hukum melalui pengadilan menyebabkan pengajuan gugatan lisan masih terbuka kemungkinannya walaupun seharusnya akan lebih pasit jika pengajuan diajukan secara tertulis

\section{Proses Penyelesaian Gugatan Lisan dalam Perkara Perdata}

Sebelum membahas proses penyelesaian perkara perdata yang diajukan secara lisan, kiranya terwujudnya ketentuan Undang-Undang No. 48 tahun 2009 yakni : " Dalam perkara perdata pengadilan membantu para pekerja keadilan, yang berusaha sekeras-kerasnya mengatasi segala suatu hambatan dan rintangan untuk dapat tercapainya peradilan sederhana, cepat dan biaya ringan.

Penjelasan tersebut di atas hal ini sesuai dengan hasil wawancara dengan hakim pengadilan negeri Padangsidimpuan yang menyatakan bahwa hendaknya sekalipun suatu gugatan yang diajukan para pihak itu secara lisan pelaksanaannya tetap mencerminkan sesuai dengan ketentuan undang-undang.

Jadi jangan sampai penyidangan berlarut-larut disebabkan gugatan yang diajukan secara lisan haruslah benar-benar bijaksana dalam memberi kesempatan bagi masing-masing pihak.

Sebagaimana diketahui bahwa dalam proses pemeriksaan sidang perkara perdata, adalah tidak terlepas dari tata cara yang dimulai dengan pengajuan gugatan, jawaban pihak tergugat, Replik Penggugat, Duplik tergugat, pembuktian, konklusi dan vonnis hakim.

Maka sehubungan dengan proses penyidangan tersebut di atas khusus dalam pemeriksaan gugatan yang diajukan secara lisan, kiranya terdapat cara-cara yang mendapatkan suatu perhatian sendiri jika dibandingkan dengan gugtan yang diajukan secara tertulis.

Diantaranya setelah pembacaaan gugatan yang dilakukan dengan perantaraan panitera sidang, biasanya adalah merupakan giliran tergugat untuk menanggapi gugatan tersebut, akan tetapi terhadap gugatan yang diajukan penggugat yang tidak bisa menulis dan membaca justru setelah pembacaan gugatan masih perlu mempertanyakan terhadap pihak penggugat sendiri, tentang bagaimana pendapatnya gugatan tersebut apakah masih ada yang kurang atau belum jelas.

Tata cara tersebut di atas lebih lanjut sebagaimana ditegaskan oleh hakim menyatakan bahwa khusus dalam perkara perdata yang gugatannya diajukan secara lisan itu serta setelah membacakan gugatan dihadapan sidang masih harus diberikan tanya jawab dengan pengugat sendiri.

Artinya tidak langsung dihentakkan tanggapan atau jawaban tergugat 
sebagaimana biasanya, yang tidak bisa membaca dan menulis tersebut. sehingga dengan memberi kesempatan sepeti ini akan dapat diketahuinya tentang isi gugatan yang dimohonkannya untuk ditulis para panitera serta akan dapat terjamin kepentingannya tentang apa yang dimintakannya untuk dituntut.

Oleh karena itu penjelasan kepada orang penggugat yang tidak membaca dan membaca setelah gugatan dibacakan, adalah merupakan suatu langkah agar sidang dapat terlaksana dengan baik dan benar-benar dapat memberi persamaan hak masing-masing pihak.

Disamping hal tersebut di atas kiranya acara memberi penjelasan kepada penguggat tentang isi gugatannya sendiri disebabkan ketidakmampuannya menulis dan membaca, juga tidak terlepas dari adanya hak untuk mengubah dan menambah gugatan tersebut. Artinya jika memang dalam gugatan tersebut merasa ada kelebihan dari apa yang seharusnya dituntutnya kiranya dengan adanya kesempatan untuk memberikan penjelasan tersebut maka akan dirubah sebagaimana mestinya yang diharapkan oleh penggugat tersebut.

Adapun cara dalam proses pemeriksaan sidang yang gugatannya diajukan secara lisan, dimana setelah tergugat memberi jawabannya atas gugatan lisan dihadapan sidang pengadilan adalah penyerahan replik yang diajukan oleh penggugat.

Dalam acara penyerahan replik inipun kiranya pihak penguggat yang telah mengajukan gugatannya secara lisan juga akan memberi jawaban langsung terhadap tanggapan tergugat atas gugatan tersebut, artinya disini penggugat tidak lagi mengomentari jawaban yang diajukan tergugat tersebut secara tertulis.

$$
\text { Melainkan secara langsung }
$$

ditanggapinya dengan cara memberi tangkisan-tangkisan terhadap pendapat tergugat atas gugatan tersebut, dengan demikian setiap acara dari proses penyelesaian gugatan secara lisan ini penggugat hanya jawaban-jawaban langsung secara lisan.
Sebagaimana dinyatakan hakim bahwa replik yang diajukan penggugat yang sebelumnya juga mengajukan gugatan secara lisan, ini tetap diberi kesempatan kepadanya untuk memberikan tanggapan-tanggapan selama persidangan dan ini secara prosedur akan dicatat seluruhnya dalam berita acara sidang oleh panitera perkara tersebut.

\section{Kekuatan Hukum dan Hambatan Gugatan secara Lisan}

Secara teoritis mengajukan gugatan untuk menuntut sesuatu hak adalah termasuk hak seseorang yang jaminan hukum keberadaannya. Oleh sebab itu siapapun termasuk hakim tidak boleh menghalangi-halangi dengan alasan apapun.

Bentuk pembuatan surat gugatan tersebut tidak ada persyaratan-persyaratan yang sifatnya khusus kecuali mengenai perumusannya baik formal maupun materil, artinya jika surat gugatan tidak memenuhi syarat formil gugatan dapat dinyatakan tidak dapat diterima sedang apabila gugatan tidak memenuhi persyaratan materil gugatan dapat dinyatakan batal.

Dengan penjelasan di atas kiranya suatu gugatan baru dapat dinyatakan mempunyai kekuatan hukum apabila surat gugatan tersebut telah dinyatakan oleh hakim bahwa surat gugatan telah memenuhi persyaratan. Oleh hakim mengistilahkan bahwa gugatan sah apabila segala sesuatunya tidak ada kekaburan lagi dan telah jelas apa yang dipersoalkan dan apa yang dimohonkan untuk dipertimbangkan hakim.

Jelasnya menurut hakim pengadilan negeri padangsidimpuan suatu surat gugatan dikatakan telah mempunyai kekuatan hukum cukup bilamana telah terpenuhi syarat formilnya, karena itu dalam proses pembuktian tinggal hal-hal yang berkaitan dengan materilnya saja. Adapun yang dimaksud materilnya adalah hal-hal yang berkaitan dengan obyek perkara serta hak yang melekat dalam hak yang dipersengketakan.

Namun yang menjadi kendala didalam proses pembuktian terbentur jika tiba saatnya pengajuan alat-alat bukti surat 
menyurat jelas penggugat yang tidak bisa tulis dan baca tidak mengetahui hal penting mendukung gugatannya, dikatakan demikian karena pengajuan bukti -bukti harus relevan dengan dalil-dalil gugatan atau dengan kata lain keberadaan alat bukti harus dapat untuk mendukung surat gugatan.

Pengajuan gugatan secara lisan diantaranya juga akan sangat berpengaruh terhadap poisisi hakim yang secara hukum perdata semestinya harus passif karena pihak-pihak yang berperkaralah yang aktif untuk membuktikan apa yang dituntut. Maka sejalan dengan itulah penerapan azas demikian tidak bisa diterapkan lagi dan ini akan merugikan pihak tergugat secara hukum karena jelas ketidak berdayaan penggugat akan membuat hakim sangat berperan.

Dalam mengajuan gugatan secara lisan tidak berarti hakim campur tangan dalam penentuan hal-hal yang sifatnya substansial tetapi yang dibantu hakim hanya hal-hal yang sifatnya proses beracara, maka oleh karena itulah secara hukum acara syah-syah saja tidak akan merugikan kepentingan pihak tergugat dalam membuat bantahan-bantahannya.

Berdasarkan uraian-uraian tersebut di atas kiranya jelaslah bahwa menggugat secara lisan syah dan diyatakan berkekuatan hukum, artinya kekuatan hukum yang dimaksudkan sebatas bersifat formal sedangkan hal yang bersifat materil tetap harus didasarkan pada pembuktian dan tetap harus merupakan peran aktif pihak yang berperkara untuk membuktikan dalil-dalil gugatan yang dituntutnya.

Sebagaimana diketahui dalam sistem peradilan perkara di bidang perdata ini, dimana masing-masing kebebasan untuk membuktikan dalil-dalil gugatannya. Artinya, pihak hakim sebagai aparat dalam sidang perdata ini hanya berperan sebagai penengah, untuk menetralisir jalannya kelancaran sidang, yang mana hal ini terbukti dari adanya tanggungjawab yang diberikan agar hakim dapat menjaga kelancaran sidang.

Memperhatikan semua data yang dihasilkan dan sebagaimana diuraikan pada bab terdahulu, kiranya jelas gugatan didalam menuntut suatu hak dalam hukum perdata adalah sesuatuyang tak bisa dilepaskan. Dikatakan demikian karena berkaitan dengan gugatan ini justru disinilah persoalan yang timbul akan dipaparkan oleh pihak yang merasa dirinya telah dirugikan, demikia juga dalam gugatan inilah hakim dapat melihat apa dan bagaimana masalah yang disengketakan.

Maka dengan kaitan penjelasan tersebut di atas itulah dapat disimpulkan bahwasanya tidak ada gugatan dalam suatu sengketa perdata, berarti tidak ada pula sengketa yang harus diperiksa dan diadili. Sehingga jelas gugatan ini merupakan suatu pertanda adanya hubungan hukum yang menimbulkan komplik serta adanya ketidak sesuaian diantara pihak-pihak dimaksud mengadakan hubungan hukum tersebut. Dalam hubungan tersebut jika ditinjau dari perkembangan prakteknya yang masih ada mengajukan gugatan secara lisan untuk memperjuangkan haknya, jika dilihat dari aturan hukumnya tetap diberikan kemungkinan bagi pihak untuk melaksanakannya.

Akan tetapi yang sering menjadi masalah dalam gugatan secara lisan ini , kiranya kurang dapat diperinci secara jelas, sebab bagi pihak yang hanya melaksanakan gugatannya secara jelas, sebab bagi pihak yang hanya melaksanakan gugatannya secara lisan sangat kurang jelas diperinci bagaimana duduk persoalannya. Sehingga dengan kondisi yagn kurang rinci mengulas fakta peristiwa dalam suatu gugatan ini, hal inilah yang menimbulkan kesulitan bagi hakim untuk mempertimbangkan setiap putusan yang akan dijatuhkanya.

Karena itulah jika semestinya gugatan tersebut diajukan dan ditulis oleh pihak sendiri atau paling tidak dapat memberikan bagi seorang kuasa dan oleh kuasa inilah yang akan menguraikan dalam gugatan.

Berdasarkan gambaran tersebut di atas itulah kiranya telah jelas bagaimana pentingnya gugatan ini dibuat secara tertulis dalam suatu sengketa perdata, dengan pengertian lain gugatan inilah yagn menjadi pedoman bagi hakim untuk memeriksa sengketa hubungan hukum atau 
kerugian seorang sebagai akibat terjadinya perjanjian.

Data yang dihasilkan dalam prakteknya kiranya telah menunjukkan perkembangan, dimana para pihak sebenarnya telah memahami jauh-jauh pentingnya surat gugatan ini. Dan oleh sebab itulah setiap mengajukan gugatan kehadapan sidang pengadilan, selalu memperhatikan syarat-syarat isi gugatan, dengan maksud agar lebih jauh dapat dihindari adanya penolakan terhadap gugatan.

Demikian jika ditinjau bagaimana pentingnya suatu gugatan ini jika memperjuangkan suatu hak melalui pemeriksaan di sidang pengadilan, sehingga dengan data demikian dinyatakan bahwasanya gugatan ini mutlak bagi suatu pemeriksaan sidang.

Pernyataan tersebut di atas hal ini dibuktikan dari adanya yurisprudensi tetap yang menyatakan pentingnya gugatan ini, artinya gugatan harus dimajukan bilamana hendak menuntut suatu hak.

\section{Praktek Pengajuan Gugatan Lisan dalam Perkara Perdata}

Memperhatikan data pengajuan gugatan lisan yang masuk pada peradilan sidang pengadilan, khususnya di pengadilan negeri Padangsidimpuian, kiranya kesempatannya masih tetap terbuka bagi setiap pencari keadilan dan perlindungan melalui sidang pengadilan. Yang mana keadaan ini tidak lain mengingat adany azas persamaan hak bagi setiap warga untuk minta keadilan, sehingga sekalipun suatu gugatan tersebut diajukan secara lisan tetap akan diadakan pemeriksaan.

Namun demikian yang masih sering menjadi kendala pada pengajuan gugatan lisan ini masih seringnya mewakilkan kepada seorang kuasa hukum, sehingga sekalipun sebenarnya apa masalah didalam sengketa itu sudah diuraikan kuasa hukum, dalam gugatan tersebut tetapi oleh pihak yang bersengketa tetap tidak akan mengetahui apa yang tertulis dalam gugatan yang dibuat kuasa tersebut.

Maka oleh sebab itulah jika kembali kepada Yurisprudensi Mahkamah Agung sebagaimana diuraikan dalam bab terdahulu, hendaknya bagi pihak yang hendak mengajukan gugatan secara lisan harus melalui administrasi pengadilan. namun demikian jika dilihat dari segi kesamarataan kesempatan bagi setiap pencari keadilan untuk mengupayakan atau memperjuangkan haknya melalui sidang pengadilan tentunya akan merasa tidak adil jika seseorang yang akan mengajukan gugatan melalui administrasi pengadilan, karena dipihak lain sebagai tergugat tentunya sudah merasa adanya ketidak pastian dalam pelaksanaan sidang, dengan kata lain sudah mencurigai adanya hubungan pihak penggugat dengan pengadilan sebelum perkara dapat dibuktikan.

Adanya perbedaan pendapat sebagaimana penulis uraikan di atas kiranya cukup beralasan, karena dengan mengingat surat gugatan ini penting bagi pemenuhan suatu hak dan acara pembuktian. Seingga pengajuan gugatan ini perlu mendapat perhatian apalagi terhadap gugatan yang diajukan secara lisan, yang kemungkinan persyaratanpersyaratan yang diperlukan kurang mendapat perhatian.

Maka sehubungan dengan itulah hendaknya tata cara ini yang dilaksanakan selama ini yaitu dengan bantuan administrasi pengadilan untuk merumuskan gugatan yang diajukan seseorang secara lisan kiranya perlu mendapat perhatian, dikatakan demikian karena dengan adanya campur tangan pihak pengadilan sebelum acara pemeriksaan sidan dimulai tentunya akan ada anggapan -anggapan yang kurang adil.

Kemudian disamping itu tentunya denan adanya campur tangan tersebut benar-benar akan mengurangi keobyektifan pemeriksaan, penulis katakan demikian karena bagaimana para pihak lawan akan tetap merasa kebebasan peradilan itu tidak murni lagi.

Dalam kaitan itulah pelaksanaan gugatan secara lisan ini hendaknya senantiasa tidak ikut campur tangan pihak pengadilan sebelum masuk dihadapan sidang pengadilan. oleh sebab itulah kuasa hukum yang harus mendampingi pihak- 
pihak yang akan berperkara lebih dari pada langsung kepada pengadilan.

Dikatakan demikian dengan memberi kewajiban keapda kuasa hukum untuk mendampingi penggugat yang akan mengajukan gugatannya secara lisan akan lebih banyak manfaatnya seperti perkaranya akan lebih cepat selesai, biaya dapat lebih ringan dan juga dapat membantu perkembangan hukum juga sangat berguna bagi hakim dalam mempertimbangkan putusannya.

Dengan demikian jelaslah bahwasanya praktek pengajuan gugatan secara lisan ini masih tetap dibutuhkan, sehingga sebahagian anggota masyarakat yang masih buta huruf tetap dapat memanfaatkan hak-haknya untuk meminta perlindungan hukum ke pengadilan. Dan pengajuan tersebut kiranya akan lebih terjamin kepastiannya bila melalui kuasa hukum, daripada langsung mencatatkannya kepada panitera pengadilan .

\section{Proses Penyelesaian Gugatan Lisan dalam Perkara Perdata}

Proses penyelesaian gugatan lisan yang diterapkan selama ini di pengadilan Negeri Padangsidimpuan, kiranya selalu berpedoman kepada undang-undang nomor 48 tahun 2009.

Dikatakan demikian karena dalam aturan ini jelas terlihat adanya suatu paksaan tanggungjawab terhadap aparat, maka oleh sebab itulah bilamana diterapkan dengan benar-benar akan dapat dilaksanakan suatu peradilan yang murni sekalipun dengan dasar suatu gugatan secara lisan.

Memperhatikan perkembangan dalam praktek kiranya masalah penyelesaian gugatan perdata yang pengajuannya dilakukan secara lisan, kiranya untuk Pengadilan Negeri Padangsidimpuan sudah tidak ada lagi masalah yang cukup berarti jika dilihat dari acara-acaranya. Karena sesuai dengan data yang penulis temukan di lapangan. Acara tersebut dilakukan adalah untuk lebih mempersingkat acara penyelesaian pemeriksaan sidang, sebab akan lebih terarah bagi penggugat yang tidak mampu menulis tersebut mengutarakan apa yang ada dalam pikirannya ketimbang dijelaskannya untuk minta dituliskan. Seperti menanyakan kembali apakah masih ada ada yang kurang dalam gugatan tersebut setelah dibacakan dihadapan dipersidangan, dan jika ada bagaimana pendapatnya serta apalagi yang perlu dimasukkan.

Berdasarkan uraian tersebut di atas kiranya proses penyelesaian gugatan yang diajukan secara lisan ini tidak jauh berbeda dengan proses pengajuan gugatan tersebut untuk didaftarkan ke sidang pengadilan, yang mana dalam proses penyelesaian inipun tetap dibutuhkan peran serta hakim yang demikian besar.

Sehingga bagi orang yang tidak mampu untuk menulis dan membaca tersebut tidak merasa hak-haknya dirugikan karena ketidak tahuannya.

Dalam acara jawab menjawab kiranya bagi masing-masing pihak yang berperkara tetap terbuka kemungkinanannya, hanya saja khusus bagi penggugat tersebut yang mengajukan gugatannya secara lisan lebih mengarahkan jawaban dan bantahannya secara lisan langsung dihadapan sidang pengadilan untuk dicatat seterusnya oleh panitera sidang. Hanya saja jika ditinjau dari efisiensi pelaksanaan sidangnya, kiranya acara yang dilakukan sebagaimana diutarakan tersebut di atas terasa kurang dan bertentangan dengan azas peradilan cepat dan biaya ringan.

Dikatakan demikian karena adanya diberi kesempatan bagi penggugat untuk terus menanggapi apa yang berkembang dalam sidang pengadilan, sehingga dengan keadaan inilah terjadi kelemahan waktu bagi pelaksanaan persidangan.

Sehubungan dengan itulah kiranya dalam proses penyelesaian gugatan lisan ini hendaknya tetap dijaga agar pelaksanaan sidang tersebut dapt berjalan lancar dan tidak memakan waktu yang cukup lama, karena bagaimanapun prinsip azas tersebut adalah didasarkan atas perintah aturan perundang-undangan, sehingga dalam praktek tidak terlalu dipermasalahkan. Atau dengan kata lain pelaksanaanya tidak terdapat hambatan 
jika dibandingkan dengan gugatan perdata yang diajukan secara tertulis.

\section{Kekuatan Hukum dan Hambatan Gugatan}

Berdasarkan data dapat disimpulkan bahwa gugatan yang diajukan secara lisan secara formil tetap punya kekuatan hukum dan tidak ada masalah bagi proses persidangan, kenyataan seperti ini terbukti dari kasus perdata yang diajukan secara lisan melalui kepaniteraan pengadilan negeri Padangsidimpuan.

Bahwa semua yang bersifat proses atas gugatan yang diajukan secara lisan kekautan hukum tetap diakui serta mempunyai akibat-akibat hukum jika ternyata keberadaan gugatan tersebut dapat dibuktikan oleh penggugat, pembuktian tersebut lebih diutamakan kepada saksi-saksi agar dalil-dalil gugatannya dapat jelas dan tegas hubungan hukumnya.

Maka sejalan dengan itulah menurut hemat penulis persoalan tertulis atau tidak bukan halangan untuk pihak yang berperkara dalam memajukan suatu tuntutan terhadap sesuatu hal yang akan dia perjuangkan lewat pengadilan, hanya saja menurut penulis yang harus jadi perhatian justru peranan hakim membantu pihak yang gugatanya diajukan secara lisan tersbut tidak merupakan kegiatan sidang yang merugikan pihak lawan yaitu tergugat. Karena jika hal ini sempat terjadi jelas telah bertentangan dengan posisi hakim dalam perkara perdata yang boleh aktif untuk mendukung satu pihak.

Sehubungan dengan itulah salah satu alat yang bisa diperankan untuk dapat mendukung gugatan lisan tidak lain melalui kesaksian-kesaksian daripada saksi-saksi yang akan dihadapkan di persidangan. Dikatakan demikian karena unutk semakin kuatnya hukum surat gugatan yang diajukan secara lisan saksi ini akan disumpah. Dan dengan kekuatan hukum sumpah yang ada pada saksi menyebabkan hakim dapat mempertimbangkan lebih jauh akan kebenaran dalil-dalil gugatan yang diajukan secara lisan.
Demikian pula melalui sumpah yng diangkat saksi tersebut hukum menganggap apa yang diterangkan dimuka sidang adalah sesuatu yang benar, sehingga kebenarannya tersebut tergantung kepada hakim untuk menyesuaikan isi keterangan tersebut dengan fakta yang terungkap dalam persidangan.

Namun terlepas dari semua persoalan di atas yang jelas praktek pengajuan gugatan secara lisan perlu mendapat pertimbangan-pertimbangan secara khusus atau tranparan di persidangan. Karena jelas dengan cara inilah pihak lain tidak dirugikan hak-hakna dan ini menurut penulis sepenuhnya tergantung kepada majelis hakim yang menyidangkan perkara tersebut.

Mendasarkan seluruh uraian-uraian tersebut aparat hakim dengan adanya gugatan yang diajukan secara lisan menjadi perantara tetapi sebatas pelaksanaan dan penerapan prosedur beracara.

Dengan kata lain bukan untuk mengajari penggugat memenangkan perkara karena persoalan meang tidaknya tergantun kepada pihak yang berperkara sejauhmana ia dapat membuktikan kebenaran gugatannya.

Dengan seluruh data-data yang telah diuraikan dimana terhadap perkara perdata diajukan secara lisan ke pengadilan negeri Padangsidimpuan tetap diproses sesuai dengan ketentuan yang hukum dapat diterima kebenarannya.

Adapun yang menjadi alasannya kenyataan menunjukkan bahwa pengadilan negeri Padangsidimpuan tetap menerima gugatan sekalipun proses pengajuannya secara lisan. Keadaan seperti ini disebabkan bahwa adanya ketentuan tidak menolak setiap kasus gugatan masyarakat. Disamping hakim perpegang kepada kenyataan dan fakta persidangan yang dihasilkan melalui proses pembuktian.

Bahwa hambatan-hambatan yang timbul dalam pembuktian prkara atas gugatan yang diajukan secara lisan adalah bukti-bukti yang diajukan berupa surat-surat pihak yang mengajukan gugatan tidak dapat diketahui kebenaran bukti-bukti tersebut dapat diterima kebenarannya. 
Karena pembuktian yang dilakukan ternyata tidak menjadi permasalahan karena dalam persidangan selama hal itu menyangkut proses, hakim membantu sepenuhnya atau mendukung selama tidak menyangkut substansi seperti penentuan hak.

\section{SIMPULAN DAN SARAN \\ Kesimpulan}

Adapun kesimpulan yang dapat diambil dari penelitian ini adalah sebagai berikut :

1. Proses pengajuan gugatan lisan dalam sistem peradilan Indonesia, masih mendapat bantuan dari pihak pengadilan dan adanya ketidak pastian apakah penting dikuasakan kepada kuasa hukum atau dapat secara langsung.

2. Dalam proses peradilan perkaraperkara perdata keberadaan suatu surat gugatan adalah sesuatu keharusan untuk dijadikan sebagai pedoman atas pemenuhan suatu hak. dan dalam penentuan persyaratan surat gugatan dalam peradilan perkara perdata, tidak terdapat kepastian mutlak.

\section{Saran}

Sedangkan saran-saran yang dapat diberikan dalam penelitian ini adalah sebagai berikut :

1. Masih perlu bagi aparat penegak hukum khususnya pihak pengadilan untuk lebih mendalami pentingnya gugatan didalam proses peradilan perkara perdata, apabila gugatan tersebut diajukan secara lisan.

2. dalam surat gugatan yang pengajuannya secara lisan, kiranya aparat pengadilan khususnya panitera agar membatasi diri didalam mengerjakan permohonan pihak yang dibuatkan surat gugatan.

\section{DAFTAR PUSTAKA}

C.S.T Kansil.1980. Pengantar IImu Hukum dan Tata Hukum Indonesia. Jakarta : Balai Pustaka.
Departemen Kehakiman RI. 1983. Bahan Pokok Penyuluhan Hukum. Jakarta: Yayasan Penganyom.

John Z. Loudoe. 1983. Fakta dan Norma dalam Hukum Acara. Surabaya: Bina Aksara

Mahkamah Agung RI. 1982. Yurisprudensi Indonesia tahun 1976. Jakarta: Press

Sumadi Suryabrata. 1983. Metodologi Penelitian. Jakarta: Press.

Soerjono Sukanto. 2010. Faktor - Faktor yang Mempengaruhi Penegakan Hukum. Jakarta : Rajawali Press .

Sri Mamuji. 2010. Penelitian Hukum Normatif. Jakarta: PT. Rajawali Press

Sudikno Mertokusumo. 1982 Hukum Acara Perdata Indonesia. Yogyakarta: Liberty.

Wirjono Prodjodikoro. 1984. Hukum Acara Perdata Indonesia. Bandung: Sumur 